\title{
TATA RUANG PEMUKIMAN DI PULAU SELU TANIMBAR BARAT (Settlement Layout in Selu Island West Tanimbar)
}

\author{
Lucas Wattimena \\ Balai Arkeologi Maluku \\ JI. Namalatu Latuhalat Kecamatan Nusaniwe Kota Ambon 97118 \\ e-mail: lucas.wattimena@yahoo.com
}

\section{INFO ARTIKEL}

Histori Artikel

Diterima: 21 Juli 2017

Direvisi: 31 Juli 2017

Disetujui: 30 Oktober 2017

\section{Keywords:}

Layout of settlement,

Selu Island West Tanimbar,

Knowledge,

Religion and ancient burial system

\section{Kata kunci:}

Tata ruang pemukiman, Pulau Selu Tanimbar Barat, Pengetahuan, Religi dan sistem penguburan kuno

\section{PENDAHULUAN}

\begin{abstract}
Selu Island is one of the small islands within the Tanimbar Archipelago. Geographically the location of Selu Island is strategic enough to connect between the great mainland of Yamdena Island and the surrounding islands. This paper provides an overview of how the characteristics of ancient settlement layout based on the folklore of the local community. The objectives of the study may be to provide 1) information about ancient settlement forms based on the folklore community. 2) as an information material for archaeological research in Moluccas especially and Indonesia generally. Why Selu Island is so interesting to be studied, because folklore spatial local community settlement is closely related to megalithic tradition. Research method using ethnoarchaeology approach. Technique of collecting data using survey, literature study and interview. The results showed that the characteristics of ancient settlement layout forms on Selu Island, West Tanimbar based on the level of public knowledge. This can be seen in the distribution layout of settlements based on folklore and archaeological evidence oriented to religious elements and ancient burial systems.
\end{abstract}

\begin{abstract}
ABSTRAK
Pulau Selu adalah salah satu pulau kecil dalam gugusan Kepulauan Tanimbar. Secara geografis letak Pulau Selu cukup strategis menghubungkan antara daratan besar Pulau Yamdena dan pulaupulau sekitarnya. Tulisan ini memberikan gambaran tentang bagaimana karakteristik tata ruang pemukiman kuno berdasarkan folklore masyarakat setempat. Tujuan penelitian kiranya dapat memberikan 1) informasi tentang bentuk-bentuk pemukiman kuno berdasarkan folklore masyarakat. 2) sebagai bahan informasi bagi penelitian arkeologi di Maluku khususnya dan Indonesia umumnya. Kenapa Pulau Selu begitu menarik untuk diteliti, karena folklore tata ruang pemukiman masyarakat setempat berkaitan erat dengan tradisi megalitik. Metode penelitian menggunakan pendekatan etnoarkeologi. Teknik pengumpulan data menggunakan survei, studi pustaka dan wawancara. Hasil penelitian menunjukan bahwa karakteristik bentuk-bentuk tataruang pemukiman kuno di Pulau Selu, Tanimbar Barat berdasarkan tingkat pengetahuan masyarakat. Hal tersebut dapat dilihat dalam pembagian tataruang pemukiman berdasarkan folklore dan bukti arkeologi yang berorientasi pada unsur religi dan sistem penguburan kuno.
\end{abstract}

\author{
Kepulauan Tanimbar memiliki \\ peran penting dalam studi arkeologi
} sebagai salah satu kawasan kunci dalam perkembangan sejarah budaya}

di Maluku. Wilayah ini juga dipandang 
di Kepulauan Asia Tenggara dan Australia. Ririmasse (2016 : 51) hasil studi yang dilakukan selama empat musim sepanjang tahun 2011-2014, memberikan gambaran yang lebih jelas tentang potensi arkeologi dan pusaka budaya yang ada di Kepulauan Tanimbar. Terdapat tiga aspek yang menjadi penanda utama dalam karakter potensi arkeologi di Kepulauan Tanimbar.

Pertama, sebaran kawasan karst dan situs-situs gua yang luas di pulau-pulau satelit di sebelah selatan dan utara seperti Pulau Selaru dan Larat-Fordata. Kedua, persebaran situs-situs pemukiman kuno, yang dikenal dengan negeri lama yang merata di seluruh wilayah Kepulauan Tanimbar bertaut dengan permukiman tradisional dan komunitas kontemporer. Karakter yang melekat pada situs-situs ini adalah sebaran temuan monumen artifisial berbentuk perahu batu yang menjadi ikon sejarah budaya Kepulauan Tanimbar. Ketiga, potensi yang memiliki korelasi dengan sejarah lokal dan komunitas setempat, yaitu situs-situs dan objek yang bertaut dengan sejarah tutur terkait asal-usul dan identitas masyarakat setempat.

Pada tahun 2016 tim penelitian Balai Arkeologi Maluku melakukan survei arkeologi di gugusan Kepulauan Tanimbar bagian barat meliputi Pulau Seira, Selu, dan Wuliaru. Wilayah Tanimbar Bagian Barat Gugusan Kepulauan Tanimbar baru pertama kali dilakukan survei arkeologi untuk melihat karakter dan potensi arkeologi dan masyarakat pendukungnya (Tim
Penelitian, 2016). Hasil survei tim penelitian Balai Arkeologi Maluku adalah situs ceruk tengkorak, situs kampung lama, dolmen batu meja, kain tenun (kain patola), perhiasan manik-manik, Koleksi gading gajah atau gigi gajah milik klan/ marga Watotomata Desa Kamatubun. Dan situs Pulau Setan (Tim Penelitian, 2016).

Diantara temuan-temuan tersebut di atas, situs Pulau Setan menarik untuk dikaji. Pulau Setan adalah nama yang diberikan oleh masyarakat Pulau Seira untuk menyebutkan situs Pulau Nus Nitu. Penyebutan Pulau Setan muncul karena berhubungan dengan kepercayaan mistik masyarakat terhadap arwah gentayangan penghuni Pulau Nus Nitu yaitu, jasad-jasad leluhur masyarakat Pulau Seira yang ruhnya tidak bisa naik ke surga. Pulau Selu tempat dimana situs Nus Nitu berada, tepatnya di bagian ujung barat pulau tersebut. Tidak ditemukan bukti arkeologi di pulau ini, namun makna kosmologis pulau ini merupakan informasi yang cukup penting dihubungkan dengan setting budaya dan kepercayaan masyarakat setempat. Makna kosmologis masyarakat setempat, Pulau Setan (Nus Nitu) adalah jembatan penghubung antara orang mati dan orang hidup. Menurut folklore masyarakat bahwa orang mati berjalan ke arah barat (Tim Penelitian, 2016 : 18). Berdasarkan folklore masyarakat Pulau Seira tentang situs Nus Nitu, maka tulisan ini membahas karakteristik tata ruang pemukiman kuno. Dengan demikian, penelitian ini bertujuan 
untuk dapat memberikan a) informasi tentang bentuk-bentuk pemukiman kuno berdasarkan folklore masyarakat. 2) sebagai bahan informasi bagi penelitian arkeologi di Maluku khususnya dan Indonesia umumnya.

Menurut penuturan tua-tua adat setempat bahwa penduduk yang mendiami Pulau Nus Nitu-Selu bermigrasi dari dua pulau yang berada sekitar 120 kilometer di sebelah barat, yaitu Dai dan Babar. Pulau Nus NituSelu sekarang sudah tidak berpunghuni lagi, dan hanya dijadikan sebagai tempat berkebun dan bertambak rumput laut oleh penduduk Pulau Seira. Catatan dalam laporan penelitian (Tim Penelitian, 2016 : 18) menyebutkan bahwa, Pulau Nus Nitu-Selu tersebut ditinggalkan, karena wabah lalat dan ikan tona-tona. Sebagaimana Parkin mengamati (Forth, 1998: 594), orientasi dan posisi spasial adalah 'dasar pokok' dari tindakan suatu upacara. Di Indonesia, ruang rumah atau sebuah desa dapat didefinisikan sebagai sebuah koleksi dari tempat tinggal dan lain bangunan diatur tertentu dengan cara lokal.

Penelitian ini menggunakan pendekatan etnoarkeologi. Teknik pengumpulan data antara lain survei, studi pustaka dan wawancara. Tanudirjo (2009: 3-4) mendefinisikan etnoarkeologi dapat dilakukan dalam beberapa tahapan, salah satunya adalah kajian etnografi guna memberikan informasi penting kepada ahli arkeologi.

\section{PEMBAHASAN}

\section{Sistem penguburan kuno}

Pernyataan yang diberikan oleh tokoh adat setempat pada November 2016 muncul ketika penulis menanyakan hubungan situs tersebut dengan kehidupan sosial budaya masyarakat Pulau Seira secara keseluruhan, yaitu (kutipan):

"Tempat yang sementara kita berdiri ini adalah tempat pamitan antara orang mati dan orang hidup, namanya ngursituli, yang artinya ngur itu pasir situli itu pamit. Jadi yang mati itu ke sana (Nus Nitu) dan hidup di sini (Pulau Selu). Jadi orang yang dosa tidak banyak jatuh menjelma menjadi bintang laut (blue sea star atau blue linckia). Sedangkan orang yang dosanya tidak banyak selamat sampai di sebelah, yang dikategorikan surga".

Penggalan kalimat di atas adalah pemahaman dan pandangan orang Seira di Tanimbar Barat tentang situs Pulau Nus Nitu-Selu. Hasil observasi menunjukan karakteristik situs Nus Nitu adalah satu dengan Pulau Selu, namun hanya dipisahkan oleh bentangan pasir putih. Kondisi geografis menunjukkan bahwa ketika air pasang daerah yang terdapat bentangan pasir tersebut tidak dapat dilalui harus menggunakan perahu menuju situs Nus Nitu. Sebaliknya ketika air surut atau meti dapat diakses dengan berjalan kaki melewati halusnya pasir pantai putih. Areal tersebut (pasir putih ketika meti) adalah tempat pamitan atau perpisahan antara orang yang hidup dan yang mati, namanya ngursituli. 


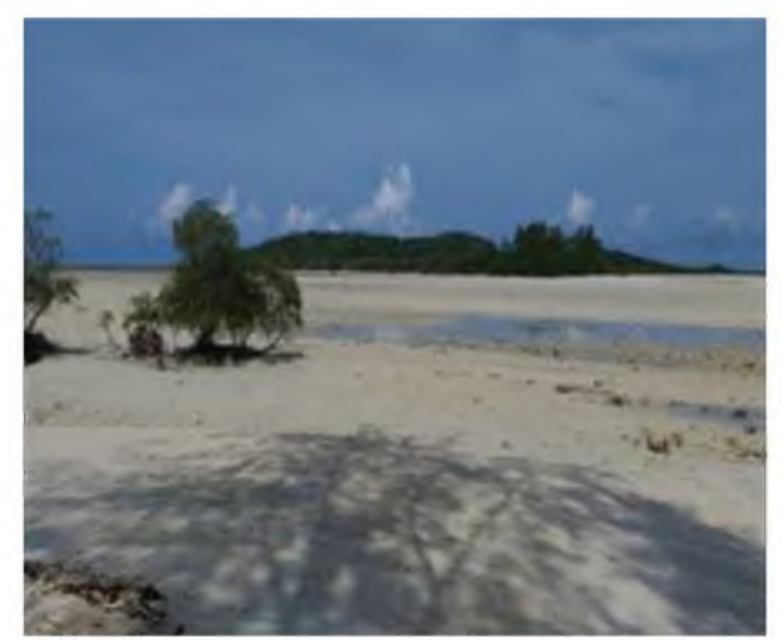

Foto 1.

Areal berpasir Situs Pulau Nus Nitu yang disebut Ngursituli

(Sumber: dokumentasi Balai Arkeologi Maluku 2016)

Pemahaman dan pandangan orang Seira bahwa situs Pulau Nus Nitu merupakan ruang kosmos antara orang mati dan orang hidup. Perspektif arkeologi dalam melihat pandangan ini adalah sebuah folklore tentang sistim hidup atau siklus hidup manusia di dunia. Holtorf (1999 : 10) mengemukakan bahwa makna di balik proses cerita tersebut menyebutkan secara eksplisit bahwa manusia mengalami proses kelahiran sampai dengan kematian. Suatu cerita rakyat merupakan peninggalan narasi, dongeng atau ritual lisan yang didasarkan pada beberapa peristiwa historis yang sebenarnya. Studi tersebut dapat membuka jalan baru untuk mendapatkan pengetahuan masa lampau manusia prasejarah. Hampir seluruh penduduk di Kepulauan Tanimbar saat ini menganut agama Nasrani. Namun praktek-praktek religi lama masih dapat diamati dalam budaya tradisional masyarakat (Ririmasse, 2016: 45).

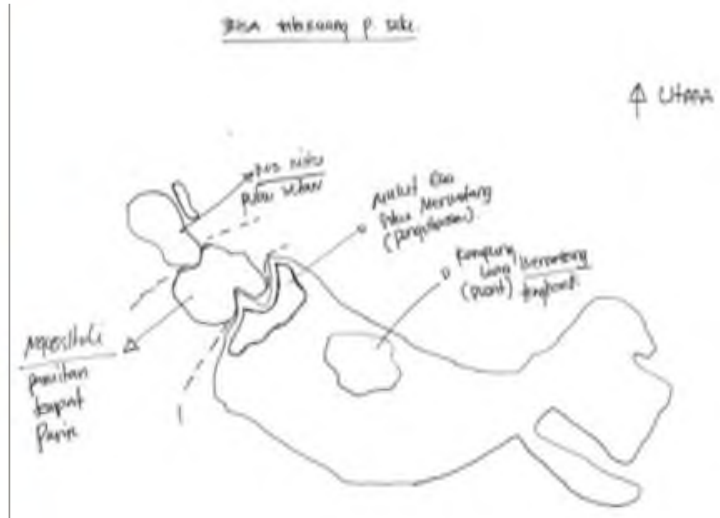

Gambar 1.

Sketsa tata ruang situs Pulau Nus Nitu-Selu (Sumber: Tim Penelitian, 2016; digambar oleh Lucas)

\section{Gambar 1 memberikan}

ilustrasi pemanfaatan lansekap pulau berdasarkan kosmologi masyarakat setempat, yaitu pembagian ruang-ruang aktivitas mendasar yang berkenaan dengan pemukiman (pusat kampung), penguburan, dan lokasi Pulau Setan. Ruang-ruang tersebut ditandai dengan bukti arkeologis berupa tinggalan megalitik. Budaya megalitik sebagai wujud benda batu meja interprestasi sebuah meja perundingan hingga integrasi masyarakat serta dolmen sebagai simbol komunal, situs keramat, ritual gaib, sesajen danpenghormatan arwah leluhur (Handoko, 2015; Sahulteru, 2015). Selain itu terdapat temuan sisa tengkorak pada ceruk gua, dan lutur batu (Tim penelitian, 2016).

Situs Pulau Nus Nitu-Selu secara keruangan dibagi menjadi tiga ruang besar, yang masing-masing ruang memiliki makna struktur sosial budaya. Kenapa demikian, karena tataruang pemukiman situs Nus NituSelu diperuntukan sesuai dengan 
domain struktur pendukungnya dari bukti arkeologi. Data utama yang diperlukan dalam analisis arkeologi keruangan mencakup tiga hal, yaitu keletakan, satuan ruang, dan hubungan interaksi antara semua unsur tersebut (Harkantiningsih et al. 1999: 183).

Struktur sosial budaya Pulau Nus Nitu-Selu yang dimaksud (gambar 2) adalah 1) Sersori tutul adalah bagian paling ujung selatan dari Pulau Nus Nitu yang menghadap langsung Kepulauan Babar. Ruang ini adalah struktur bagi orang mati yang sudah dewasa (sersori tutul artinya orang-orang tua); 2) Rokrokwanfamarengea adalah ruang anak-anak, yang terdiri dari dua ruang, yaitu ruang rokrokwanfamarenea untuk anak-anak remaja, dan tawu riro adalah ruang untuk anak-anak yang mati di bawah umur tiga belas tahun (bukan remaja); dan 3) mitu rir lingat (nitur lingat) yang berarti tempat berkumpul orang tua-tua untuk minum-minuman tradisional sopi. Menurut Ignold (Barrett, 1999 : 24) pemandangan (landscape) adalah bukan totalitas yang dapat dilihat oleh kita sendiri atau dilihat oleh orang lain, melainkan sebaliknya merupakan suatu pemandangan dunia di mana kita berdiri dalam perspektif sudut pandang di sekitar kita.

Pengetahuan Orang Seira, Tanimbar Barat Maluku Tenggara Barat tentang situs Pulau Nus Nitu-Selu telah tertuang dalam pemaknaan ruang dan makna bagi orang mati. Setiap manusia mati mempunyai ruang untuk ditempati, yang dihubungkan oleh jembatan kehidupan antara orang mati dan hidup. Dalam kajian keruangan diyakini bahwa suatu kawasan situs atau pemukiman, tidak dibentuk secara acak, namun melalui prinsip-prinsip tertentu. Kusmartono (2011: 78) situssitus yang ditemukan di Kalimantan Bagian Tengah mengindikasikan potensi untuk menggambarkan adanya tradisi yang bertahan dengan berbasis agama peradaban masa lalu adalah Haringen. Tinggalan arkeologis yang ditemukan di Situs mencerminkan perilaku manusia masa lalu mencoba untuk menyesuaikan diri dengan lingkungan sekitarnya. Dengan demikian, terdapat hubungan yang erat antara pemilihan calon lokasi kegiatan dan strategi manusia untuk memenuhi kebutuhan dasarnya. Di antara situs-situs di Kalimantan di bagian tengah yang Sampai dengan saat ini, salah satu tradisi yang menunjukkan kontinuitas budaya tua adalah penguburan. Maryone (2016: 17) Nilai-nilai yang terdapat pada sistem penguburan (megalitik) di Papua yaitu: nilai religius, jujur, toleransi, disiplin, kerja keras, mandiri, demokratis, rasa ingin tahu, semangat kebangsaan, cinta tanah air, menghargai prestasi, bersahabatlkomunikatif, cinta damai, peduli sosial, dan peduli lingkungan. Pola ruang pemukiman kuna dan tradisional di Maluku yang direkayasa dengan mengacu pada prinsip dan nilai yang diyakini masyarakatnya (Ririmasse 2007: 102). 


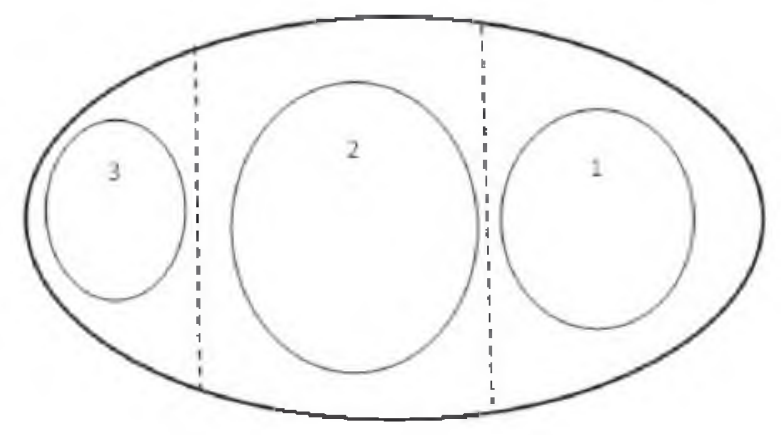

Gambar 2.

Sketsa struktur sosial budaya tata ruang situs

Pulau Nus Nitu-Selu

(Sumber: Tim Penelitian, 2016)

\section{Anasir religi lainnya}

Situs (pusat) kampung lama Wermatang berada pada ketinggian 105 meter di atas permukaan laut (dpi). Pusat kampung Wermatang ditandai oleh meja batu dan beberapa susunan batu, yang tampak sebagai pondasi dan umpak tiang rumah. Jejak-jejak pemukiman (di mana?) diantaraanya adalah susunan batu atau lutur yang tampak rata dengan tanah, sebagai bekas pondasi rumah. Keberadaan megalitik berupa batu meja batu meja dianggap sebagai pusat kampung, dan di keempat penjuru mata angin adalah lokasi penempatan rumahrumah penduduk (Tim Penelitian, 2016: 24).

Anasir religi pada pusat Kampung Wermatang (gambar 3) dibagi ke dalam tiga kelompok besar, yaitu I adalah ruang untuk orang mati yang beri kode dengan no 6. Areal ini khusus berkaitan dengan penguburan. Di areal no. 6 tidak dilakukan aktivitas harian.

II adalah ruang sumber kehidupan. Menurut informasi dari tetua adat di Pulau Seira, Kampung Lama Wermatang (?) pada masa lampau hanya terdiri dari empat keluarga. Keempat matarumah/klan/fam tersebut adalah (1) Lebitduan klan/mata rumah laki-laki, (2) Ratumnata, (3) Ratsina dan (4) Wakan Kal. Saat ini, keturunan marga Wermatang bermukim di Pulau Seira, tepatnya di Desa Kamatubun (Tim Penelitian 2016: 23).

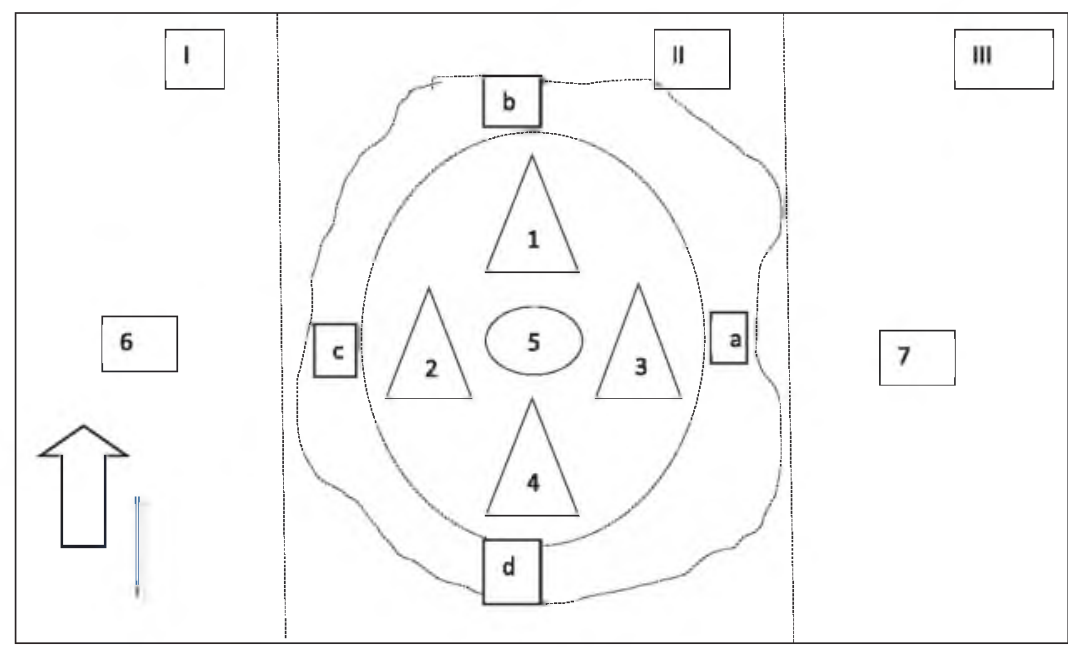

Gambar 3.

Sketsa tata ruang (?) permukiman kuno (pusat kampung) Wermatang, Pulau Selu, Tanimbar Barat, Maluku Tenggara Barat (Sumber: Tim Penelitian, 2016). Huruf: a, b, c, dan d adalah megalitik dolmen. Angka 1,2,3,4 adalah rumah klan. 
Informasi tentang kapan ruang pemukiman kuna dan tradisional mereka datang sudah tidak diketahui di Maluku yang direkayasa dengan oleh masyarakat, namun mereka mengacu pada prinsip dan nilai yang mengetahui bahwa kedatangan mereka jauh sebelum bangsa kolonial. Situs megalitik dolmen atau watu flauru/floru (lihat gambar 3 pada angka nomor 5) letaknya ditempatkan di depan (tengah) diyakini masyarakatnya. Pola rekayasa ruang masa lalu di Maluku juga dapat menjadi cermin kepercayaan masyarakat masa lalu di Maluku.

Hasil observasi menunjukkan bangunan rumah-rumah (lihat gambar 3 angka 1, 2, 3 dan 4) tersebut.

Rekonstruksi tata ruang permukiman Kampung Wermatang mengindikasikan konsep kosmologis tentang tingkat pengelompokkan masyarakatsecaravertikaldanhorizontal. Pengelompokkan vertikal didasarkan pada kesamaan leluhur berasal dari wilayah yang sama (Pulau Dai dan Babar). Sedangkan pengelompokkan secara horizontal pengelompokkan berdasarkan territorial (Ririmasse dalam Handoko 2015; Wattimena 2013, 2016).

Ruang III atau nomor 7 adalah areal berkebun dan berladang, menunjukkan anasir religi yang behubungan dengan kebutuhan hidup atau kelangsungan hidup manusia. Pengaturan tata ruang skala mikro dapat dilihat dari penempatan dolmen di belakang rumah keluarga Wermatang (lihat gambar 3), dan digunakan sebagai medium sembahyang. Berbeda dengan dolmen (nomor 5 ruang II) adalah pusat penanda kampung. Ririmasse (2007 : 102-103) Dalam kajian keruangan, diyakini bahwa suatu kawasan situs atau pemukiman, tidak dibentuk secara acak, namun melalui prinsip-prinsip tertentu. Demikian halnya dengan pola

bahwa struktur kampung secara makro (pada Pulau Nus Nitu-Selu?) diberi ruang-ruang sesuai konteks fungsi dan makna (lihat penjelasan sebelumnya). Bowie (Insoll, 2004 : 9) melihat perspektif agama atau kepercayaan tradisional didefinisikan sebagai 1) Oral, or if literate, lacks written/formal scriptures and creeds. 2) 'This worldly'. 3) Confined to single language or ethnic group. 4) Form basis from which world religions have developed. 5) Religious and social life are inseparable. Folklore tentang kronologi makna situs Nus Nitu-Selu adalah muncul hari (malam), namun hari baru (siang) bagi orang mati. Sedangkan pada arah timur situs Kampung Wermatang adalah matahari terbit terkandung unsur hidup, karena areal tersebut adalah lokasi perladangan.

\section{PENUTUP}

Situs Pulau Nus Nitu-Selu di Kepulauan Tanimbar merupakan sebuah situs multi komponen yang dibagi-bagi menurut fungsinya sebagai pemakama, hunian, dan pemujaan leluhur. Tata ruang permukiman Pulau Nus Nitu-Selu membentuk lingkaranlingkaran yang berawal dari pusat dan 
mengembang hingga keluar lingkaran. penguburan diposisikan di sebelah barat Tata ruang makro situs-situs di Pulau kampung lama, dan kegiatan kehidupan Nus Nitu-Selu dapat ditarik garis lurus dan perladangan ditempatkan di sebelah mengikuti arah mata angin dari barat timur kampung.

ke timur. Penempatan ruang-ruang Penelitian sejogyanya dapat yang demikian sesuai dengan konsep memberikan kontribusi informasi kosmologi setempat yang berpatokan penting, hubungannya dengan ceritapada arah matahari terbit (timur) dan cerita rakyat berdasarkan situs-situs terbenam (barat). Oleh karena itu, arkeologi. Sehingga dapat dilakukan pembagian lansekap Pulau Nus Nitu- pemetaan secara etnohistoris dan oral Selu adalah penempatan kampung lama historic berdasarkan bukti arkeologis.

Wermatang pada titik pusat pulau, lokasi 


\section{DAFTAR PUSTAKA}

Barrett, John C. 1999. "The Archaeology and Antrhopology of Landscape Shaping Your Landscape" pp. 21-30 in Chrononologies Of Landscape. London And New York: Routledge Taylor and Francis Group.

Forth, G. 1998. "Ritual Implications of Settlement Change An Eastern Indonesian Example." In Bijdragen tot de Taal-, Land- en Volkenkunde 154 (4), Leiden, 593-612

Handoko, Wuri. 2015. "Budaya Megalitik Di Kepulauan Lease: Maluku Antara Tradisi Dan Budaya Integrasi" pp. 377-96 in Pernak Pernik Megalitik Nusantara. Yogjakarta: Galang Press.

Holtorf, Amy Gazin-Schwartz and Cornelius. 1999. Archaeology and Folklore. New York and London: Routledge Taylor and Francis Group.

Harkantiningsih, Naniek T.S., Bagyo Prasetyo, Yusmaini Eriawati, Aryandini Novita, Nurul Laili eds. 1999. Metode Penelitian Arkeologi. Jakarta : Pusat Penelitian Arkeologi Nasional.

Insoll, Timothy. 2004. Archaeology, Ritual, Religion. USA dan London: Routledge Taylor and Francis Group.

Kusmartono, Vida. 2011. Preliminary Study on Burial Characteristhic of Harigen. Naditira Widya 5(1). 78-91.

Maryone, Rini. 2016. Keberagaman Sistem Penguburan di Papua (Kajian Etnoarkeologi). Jurnal Papua 8(1). 17-32.

Ririmasse, Marlon N. R. 2007. "Ruang Sebagai Wahana Makna". Kapata Arkeologi 3 (5). 72-106.

Ririmasse, Marlon N.R. 2016. "Arkeologi Kepulauan Tanimbar Hasil Penelitian 2011-2014 dan Arah Pengembanganya. Naditirawidya 10 (1): 41-52.

Sahulteru, Wuri Handoko dan Marlyn. 2015. "Kearifan Budaya dan Keberlanjutan Religi Megalitik Pulau Seram Propinsi Maluku" pp. 397-412 in Pernak Pernik Megalitik Di Nusantara. Yogyakarta: Galang Press.

Tanudirjo, Daud Aris. 2009. "Memikirkan Kembali Etnoarkeologi." Jurnal Papua 2(1):1-15.

Tim Penelitian. 2016. Arkeologi Pulau Serra, Tanimbar Barat Maluku Tenggara Barat. Balai Arkeologi Ambon.

Wattimena, Lucas. 2013. Permukiman Orang Huaulu di Seram Utara, Kabupaten Maluku Tengah. Balai Arkeologi Ambon.

Wattimena, Lucas. 2016. "Batu Teong di Pegunungan Kota Ambon, Kepulauan Ambon Lease." Kapata Arkeologi 12(2): 213-20. 